\title{
Expression mechanism of tryptophan hydroxylase 1 in mouse islets during pregnancy
}

\author{
Hitoshi lida', Takeshi Ogihara', Mun-kyeong Min ${ }^{5}$, Akemi Hara', Yeong Gi Kim5, \\ Kyoko Fujimaki ${ }^{1}$, Motoyuki Tamaki ${ }^{6}$, Yoshio Fujitani ${ }^{1,4}$, Hail Kim ${ }^{5}$ and \\ Hirotaka Watada ${ }^{1,2,3}$ \\ ${ }^{1}$ Department of Metabolism and Endocrinology, ${ }^{2}$ Center for Molecular Diabetology, ${ }^{3}$ Center for Therapeutic \\ Innovations in Diabetes, and ${ }^{4} J a p a n$ Science and Technology Agency-Core Research for Evolutionary Science and \\ Technology Program, Juntendo University Graduate School of Medicine, 2-1-1 Hongo, Bunkyo-ku, Tokyo 113-8421, \\ Japan \\ ${ }^{5}$ Graduate School of Medical Science and Engineering, Korea Advanced Institute of Science and Technology, \\ Daejeon 305-701, Republic of Korea \\ ${ }^{6}$ Diabetes Therapeutics and Research Center, Tokushima University, Tokushima 770-8503, Japan
}

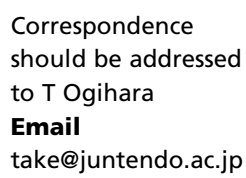

\begin{abstract}
Serotonin signaling plays key roles in augmentation of pancreatic $\beta$-cell function during pregnancy. Increased expression of tryptophan hydroxylase 1 (Tph1), a rate-limiting enzyme for serotonin synthesis by lactogenic hormones, is involved in this phenomenon. To investigate its mechanisms, we here performed $5^{\prime}$-RACE and identified $\beta$-cell-specific transcription initiation sites for Tph1. Prolactin enhanced the expression of mRNA containing these exons; however, reporter gene plasmids containing the proximal 5 -flanking region of these exons did not show prolactin responsiveness in MIN6 cells. Prolactin-induced Tph1 expression was inhibited by a Jak2 inhibitor and was partially inhibited by an MEK1/2 or PI3K inhibitor. Therefore, we analyzed interferon $\gamma$-activated sequences (GAS) and found GAS-A about 9-kbp upstream of the transcription start site. The reporter gene plasmid containing the GAS-A region linked to a heterologous promoter showed increased promoter activity by prolactin, which was inhibited by the forced expression of a dominant-negative mutant form of Stat5A and a Jak2 inhibitor. Chromatin immunoprecipitation analysis showed that prolactin treatment augmented Stat 5 binding to the GAS-A region in MIN6 cells, as well as in isolated mouse islets, and that Stat5 recognized the GAS-A region in pregnant mouse islets. In addition, the transactivation activity of Stat5 was enhanced by prolactin through the Erk and PI3K pathways in MIN6 cells. Finally, serotonin expression was attenuated in islets of $\beta$-cell-specific Stat5-deficient mice compared with that of control littermates during pregnancy. Our findings suggest that prolactin-induced Tph1 expression is mediated by the activation of Jak2/Stat5, Erk, and PI3K pathways in $\beta$ cells.
\end{abstract}

$$
\begin{aligned}
& \text { Key Words } \\
& \text { - } \beta \text { cell } \\
& \text { - } \text { islet } \\
& \text { - } \text { serotonin } \\
& \text { - Tph1 } \\
& \text { - prolactin } \\
& \text { - Stat } \\
& \text { - Erk } \\
& \text { - PI3-kinase } \\
& \text { - pregnancy } \\
& \text { - MIN6 cell }
\end{aligned}
$$

\section{Introduction}

Glucose homeostasis is maintained through the coordinate activities of the insulin-producing pancreas and glucose-storing tissues, including muscle, liver, and adipose tissue. Pancreatic $\beta$ cells respond to fluctuations in blood glucose to secrete appropriate amounts of insulin; therefore, disruption of insulin release causes glucose 
intolerance. The capacity of insulin secretion from a pancreas is governed by its $\beta$-cell mass and the capacity of each $\beta$ cell to release insulin. Type 1 diabetes is characterized as insulitis triggered by an autoimmune disorder against $\beta$ cells, leading to an absolute defect of insulin release. In type 2 diabetes, insufficient insulin secretion to compensate for insulin resistance causes hyperglycemia. Previous studies showed that a reduction in $\beta$-cell mass was observed in type 1 as well as type 2 diabetic patients, suggesting that the preservation of or increase in $\beta$-cell mass is a promising approach to maintain normoglycemia (Butler et al. 2003, Meier et al. 2005). Whereas islet mass increases during the prenatal and neonatal period, the appearance of proliferation markers in $\beta$ cells decreases with ageing (Meier et al. 2005, 2008, Gregg et al. 2012, Saisho et al. 2013). Although pancreas or islet transplantation would be an effective approach to augment $\beta$-cell mass, there is limited availability of pancreata for transplantation.

Placental lactogens induce glucose intolerance during pregnancy, which leads to dramatic increases in insulin release to maintain blood glucose levels. Pathological analysis of pregnant rodent models demonstrated that $\beta$-cell mass increases daily (Buchanan \& Xiang 2005, Rieck $\&$ Kaestner 2010). Numerous studies have shown that the prolactin receptor plays an important role in the augmentation of $\beta$-cell function in pregnant rodent models. Indeed, heterozygous prolactin receptor knockout mice exhibited mild glucose intolerance and failed increase in $\beta$-cell mass during pregnancy (Huang et al. 2009, Hughes \& Huang 2011). In addition, treatment with prolactin or placental lactogens evoked $\beta$-cell proliferation in isolated islets. These data suggest that mechanisms of $\beta$-cell compensation during pregnancy are different from those during overnutrition (Chang-Chen et al. 2008). Recently, our group showed that serotonin (5-hydroxytryptamine (5-HT)) is highly expressed in mouse and human islets during pregnancy and contributes to increases of $\beta$-cell proliferation as well as insulin secretion (Kim et al. 2010). At the middle stage of pregnancy, expression of a rate-limiting enzyme for 5-HT synthesis, tryptophan hydroxylase 1 (Tph1), is upregulated $\sim 500$-fold. This dramatic change of gene expression results in the enhanced expression of 5-HT in islets during pregnancy. The treatment of isolated mouse islets with 5 -HT increased the proliferation of $\beta$ cells, at least in part through the $\mathrm{G} \alpha(\mathrm{q})$-linked 5-HT receptor called the 5-HT2b receptor (Kim et al. 2010). In addition, activation of the inotropic 5-HT receptor, 5-HT3a receptor, results in enhanced glucose-induced Ca influx, which plays a central role in enhanced glucose-stimulating insulin secretion during pregnancy (Ohara-Imaizumi et al. 2013). Inhibition of 5-HT synthesis by dietary restriction of tryptophan or a Tph1 inhibitor induced glucose intolerance in pregnant mice without affecting insulin sensitivity (Kim et al. 2010). The expression of Tph1 was enhanced by prolactin; however, its precise mechanism has not been fully elucidated (Kim et al. 2010, Schraenen et al. 2010).

The mechanism involved in the prolactin-induced expression of Tph1 in $\beta$ cells is one of the key mechanisms that compensate for insulin resistance during pregnancy. In this study we investigated the mechanisms by which prolactin regulates Tph1 mRNA expression in a $\beta$-cell line and in islets from pregnant mice.

\section{Materials and methods}

\section{Cell culture and islet isolation}

MIN6 mouse insulinoma cells were cultured in DMEM supplemented with 15\% (v/v) FCS, 10 mM HEPES, and 1\% (v/v) penicillin and streptomycin (Life Technologies) under $5 \% \mathrm{CO}_{2}$ at $37^{\circ} \mathrm{C}$. $\beta \mathrm{TC} 3$ mouse insulinoma cells were cultured in DMEM supplemented with $15 \%(\mathrm{v} / \mathrm{v})$ horse serum, 2.5\% (v/v) FCS, and 1\% (v/v) penicillin and streptomycin. Isolation of mouse islets was performed as described previously (Iwashita et al. 2007). For chromatin immunoprecipitation (ChIP) analysis, islets were isolated from non-pregnant and pregnant mice at gestational age (G) 12.5 days. Mouse islets were cultured in RPMI1640 supplemented with $10 \%$ (v/v) FCS, and $1 \%$ $(\mathrm{v} / \mathrm{v})$ penicillin and streptomycin. After pretreatment with or without $100 \mu \mathrm{M}$ AG490 (a tyrosine kinase inhibitor of JAK2) (Sigma-Aldrich), $10 \mu \mathrm{M} \mathrm{U0126}$ (a selective inhibitor of MEK1/2) (WAKO, Tokyo, Japan), or $50 \mu \mathrm{M}$ LY-294002 (an inhibitor of PI3Ks) (Cell Signaling, Tokyo, Japan) for $30 \mathrm{~min}$, MIN6 cells, $\beta$ TC3 cells, or mouse islets were stimulated with or without $44.2 \mathrm{nM}$ of prolactin (R\&D Systems, Minneapolis, MN, USA) for the indicated times.

\section{Quantitative RT-PCR}

MIN6 cells $\left(1 \times 10^{6}\right)$, $\beta$ TC 3 cells $\left(1 \times 10^{6}\right)$, and $\sim 50$ isolated mouse islets were seeded in six-well plates and treated with or without $44.2 \mathrm{nM}$ of prolactin for $24 \mathrm{~h}$. Total RNA was extracted from the cells using RNeasy kit (Qiagen) according to the manufacturer's instructions.

Published by Bioscientifica Ltd. 
Complementary DNA was synthesized using SuperScript III Reverse Trancriptase (Invitrogen). Reaction mixtures for PCR were prepared using FAST SYBR Green Master Mix (Life Technologies), and quantitative PCR was performed using the 7500 Real-Time PCR System (Life Technologies). Specific primers used for each gene are as follows: mouse Tph1 (forward: 5'-TGGACATGCCAAAGTCAAGCCCTTT-3', reverse: 5'-GTACTTCAGTCCAAACGGGCGCTTC-3'), mouse prolactin receptor (gene symbol Prlr; forward: 5'-TCTCTGTGGAGGTGAGCATCGCA-3', reverse: 5'-TCAGGCTGGCCCTTCTTCTTGC-3'), and mouse TATA-binding protein (gene symbol Tbp; forward: 5'-GCTGCAGTCATCATGAGAATAAGAG-3', reverse: 5'-CACCATGTTCTGGATCTTGAAGT-3'). The condition for PCR was 40 cycles of $95^{\circ} \mathrm{C}$ for $3 \mathrm{~s}$ and $60^{\circ} \mathrm{C}$ for $30 \mathrm{~s}$.

\section{5'-RACE}

Total RNA was extracted from MIN6 cells as described above, and the $5^{\prime}$ ends of the mRNA were analyzed by the GeneRacer kit (Invitrogen) according to the manufacturer's instructions. Briefly, total RNA was treated with calf intestinal alkaline phosphatase to remove $5^{\prime}$ phosphates, followed by treatment with tobacco acid pyrophosphatase to remove the $5^{\prime}$-cap structure. Decapped mRNA was ligated to the GeneRacer RNA oligo by T4 DNA ligase. mRNA was transcribed into cDNA using SuperScript III Reverse Transcriptase, and then the cDNA was amplified by PCR using GeneRacer $5^{\prime}$ primer and the Tph1 gene specific reverse primer (5'-GAGAGGACGGTGGCGTGCGA-3'). After purifying the PCR products, nested PCR was performed using GeneRacer $5^{\prime}$ primer and the nested Tph1 gene-specific reverse primer (5'-CTGATCGGGCGAGTCCACCGA-3'). After purification, PCR products were subcloned into the pCR2.1-TOPO plasmid vector (Invitrogen) and sequenced. The newly determined Tph1 exon 1 variant was deposited in the DNA Databank of Japan (accession number: LC008513).

Transcriptional variants of Tph1 were analyzed by amplifying its cDNA from MIN6 cells and mouse islets using each specific forward primer for exon 1a (5'-GAAGTATGTCCACGGGCCTC-3'), exon 1b (5'-ATTGGCCGTTCTGACGATGC-3'), exon 1c (5'-CAGCAAGGACGGGATCAACT- $3^{\prime}$ ), and the reverse primer designed in exon 3 ( $5^{\prime}$-TCCGGGACTCGATGTGTAAC-3'). $\beta$-actin (gene symbol; $A c t b$ ) was amplified as an internal control (forward: 5'-CATCCGTAAAGACCTCTATGCCAAC-3', reverse: 5'-ATGGAGCCACCGATCCACA-3'). Total RNA of mouse brain stem cells was purchased from Takara Bio, Inc. (Tokyo, Japan) as a positive control.

\section{Plasmid constructs}

Upstream sequences of various lengths of mouse Tph1 exon 1 or exon 2 were amplified by PCR using each primer set as described in the Supplementary Table, see section on supplementary data given at the end of this article, and subcloned into the reporter gene plasmid pFox Luc One (pFLO) (Smith et al. 1999) or pGL3 (Promega). Two putative Stat5-binding elements and a mutated element were constructed by annealing two oligonucleotides (GAS-A forward: 5'-GATCTGTCCCCAGCTCTTCCCAGAAAGCCCTGAGGTG-3', reverse: 5'-GATCCACCTCAGGGCTTTCTGGGAAGAGCTGGGGACA-3', GAS-B forward: 5'-GATCTCTTCTTGGCTTACGGGAAGACGGTTTAG-3', reverse: 5'-GATCCTAAACCGTCTTCCCGTAAGCCAAGAAGA-3', GAS-A Mutation forward: 5'-GATCTGTCCCCAGCTCTGACCAATAAGCCCTGAGGTG-3', reverse: 5'-GATCCACCTCAGGGCTTATTGGTCAGAGCTGGGGACA-3'). $6 \times$ GAS-A, $6 \times$ GAS-B, or $6 \times$ GAS-A Mutation were subcloned into the reporter gene plasmid containing the prolactin minimal promoter, pFLO-Prl (Deering et al. 2009), and pFLO-Tph1 ex1b-760bp via BglII and BamHI restriction sites as described in a previous report (Smith et al. 1999). The reporter gene plasmid containing upstream activating sequences for galactose and TATA box (UAS-TATA-Luciferase) was a generous gift from Dr Kajimura (University of San Francisco) (Seale et al. 2007). The Stat $5 A$ cDNA sequence was amplified using the primer set described in Supplementary Table, and subcloned into the expression vector for GAL4-DBD (pM) (Takara Bio, Inc.) via EcoRI and MluI restriction sites. The expression vectors for Stat $5 \mathrm{~A}$ and a dominant-negative form of Stat $5 \mathrm{~A}$ were a generous gift from Dr Shannon L Kellenher (Pennsylvania State University, USA) (Qian et al. 2009). Cloned DNA fragments that were amplified by PCR were validated by direct sequencing.

\section{Transient transfection and luciferase assay}

MIN6 cells $\left(1 \times 10^{6}\right)$ were seeded in six-well plates, transfected with $1 \mu \mathrm{g}$ of reporter gene plasmid, and cotransfected with or without $0.2 \mu \mathrm{g}$ of expression vector encoding Stat5A or a dominant-negative form of Stat $5 \mathrm{~A}$ using Effectene transfection reagent (Qiagen) according to the manufacturer's instructions. At $24 \mathrm{~h}$ after transfection, the cells were treated with $44.2 \mathrm{nM}$ of prolactin. The cells were then harvested and lysed in Reporter Lysis buffer (Promega). The luciferase assay was performed using Luciferase Assay Substrate (Promega). The relative firefly luciferase activity was normalized by the protein

Published by Bioscientifica Ltd 
concentration, which was measured using the Pierce $660 \mathrm{~nm}$ Protein Assay kit (Thermo, Yokohama, Japan). Each experiment was repeated at least four times.

\section{Electrophoretic mobility shift assay}

MIN6 cells were seeded in 10-cm dishes, and isolated nuclear extracts were subjected to electrophoretic mobility shift assay (EMSA) according to the procedure described previously (Sadowski et al. 1993). The GAS-A oligonucleotides (5'-GATCTGTCCCCAGCTCTTCCCAGAAAGCCCTGAGGTG-3') and GAS-A Mutation oligonucleotides (5'-GATCTGTCCCCAGCTCTGACCAATAAGCCCTGAGGTG-3') labeled by IRDye700 were purchased from Integrated DNA Technologies (Coralville, IA, USA). One microgram of nuclear protein extract was incubated in EMSA buffer (10 mM HEPES (pH 7.9), $75 \mathrm{mM} \mathrm{KCl,} 2.5 \mathrm{mM}$ $\mathrm{MgCl}_{2}, 0.1 \mathrm{mM}$ EDTA, $1 \mathrm{mM}$ DTT, 3\% (w/v) Ficoll, $0.05 \%$ (w/w) poly(dI-dC), $7.35 \mu \mathrm{M}$ BSA) for $10 \mathrm{~min}$ at room temperature with $5 \mu \mathrm{l}$ rabbit serum or $5 \mu \mathrm{l}$ of a STAT5 antibody (Santa Cruz). For competitive analysis, we used a 50-fold or 100-fold excess of non-labeled oligonucleotides (5'-CTGTCGTTTCCTGGAATTGGCCATACCTGGAAGAGGCC-3'). Reaction mixtures were electrophoresed through a 5\% non-denaturing polyacrylamide gel. After electrophoresis, the gels were dried and scanned by the Odyssey infrared imaging system (LI-COR, Lincoln, NE, USA).

\section{ChIP assay}

MIN6 cells $\left(3 \times 10^{7}\right)$ were treated with trypsin/EDTA, and $\sim 150$ mouse islets were suspended in $\mathrm{Ca}^{2+}$-free Hank's balanced salt solution for $30 \mathrm{~min}$ at $37^{\circ} \mathrm{C}$, followed by adjusting to $1 \mathrm{mM}$ EGTA for dissociation, and resuspended in PBS. DNA-protein complexes were cross-linked by $1 \%$ $(\mathrm{w} / \mathrm{v})$ formaldehyde and incubated at room temperature for $10 \mathrm{~min}$, followed by the addition of $0.2 \mathrm{M}$ glycine to stop the cross-linking reaction. The cells were washed twice with ice-cold PBS and three times with $10 \mathrm{ml}$ of MC lysis buffer (10 mM Tris-Cl (pH 7.5), $10 \mathrm{mM} \mathrm{NaCl}_{2}, 3 \mathrm{mM}$ $\mathrm{MgCl}_{2}$, and $\left.0.5 \%(\mathrm{v} / \mathrm{v}) \mathrm{NP}-40\right)$. The pellet was resuspended in $1 \mathrm{ml}$ of MNase buffer (10 mM Tris-Cl (pH7.5), $10 \mathrm{mM}$ $\mathrm{NaCl}, 3 \mathrm{mM} \mathrm{MgCl}, 1 \mathrm{mM} \mathrm{CaCl} 2,4 \%$ (v/v) NP-40, and $1 \mathrm{mM}$ phenylmethylsulphonyl fluoride (PMSF)), to a final volume of $1.5 \mathrm{ml}$. DNA was fragmented by $10-100 \mathrm{U}$ of Micrococcal Nuclease for $10 \mathrm{~min}$ at $37^{\circ} \mathrm{C}$. To stop the enzymatic reaction, the sample was adjusted to $3 \mathrm{mM}$ EGTA, $1 \mathrm{mM}$ PMSF, $1 \times$ Halt protease and phosphatase inhibitor cocktail (Life Technologies), 1\% (v/v) SDS and $200 \mathrm{mM} \mathrm{NaCl}$. The nuclei were subsequently sheared on ice with 15 pulses (MIN6 cells) or 40 pulses (mouse islets) of $5 \mathrm{~s}$ sonication with a cooling period $15 \mathrm{~s}$, using Sonicator (Qsonica, Newtown, CT, USA). Supernatants were diluted $1: 5$ by adding FA lysis buffer (50 mM HEPES adjusted to $\mathrm{pH} 7.5$ with $\mathrm{KOH}, 150 \mathrm{mM} \mathrm{NaCl}, 1 \mathrm{mM}$ EDTA, 1\% (v/v) TritonX-100, 0.1\% (w/v) sodium deoxycholate, and $0.1 \%(\mathrm{v} / \mathrm{v})$ SDS) containing $1 \mathrm{mM}$ PMSF and $1 \times$ Halt protease and phosphatase inhibitor cocktail. Then 50$100 \mu \mathrm{l}$ of protein A/G PLUS-Agarose beads (Santa Cruz) were added and incubated at $4{ }^{\circ} \mathrm{C}$ for $4 \mathrm{~h}$ to preclean the chromatin. After this incubation, the samples were centrifuged at $300 \boldsymbol{g}$ for $5 \mathrm{~min}$ at room temperature, and $10 \%$ of the supernatant was taken as the input. The samples were incubated with protein A/G PLUS-Agarose beads (50-100 $\mu \mathrm{l}$ ) conjugated to $1 \mu \mathrm{g}$ of a STAT5 antibody (sc-835x; Santa Cruz) overnight at $4{ }^{\circ} \mathrm{C}$ on an end-over-end rotator. The STAT5 antibody-conjugated beads were washed and the chromatin was eluted by $100 \mu$ l of ChIP elution buffer. Two percent (w/w) of Pronase (Roche) was added and the eluted chromatin fragments were reverse cross-linked by incubation at $42^{\circ} \mathrm{C}$ for $2 \mathrm{~h}$, followed by incubation at $65^{\circ} \mathrm{C}$ for $6 \mathrm{~h}$. The DNA was purified using the QIAquick PCR purification kit (Qiagen) according to the manufacturer's instructions.

The relative amount of Stat5 binding was determined by PCR using the primers specific for the mouse Tph1 promoter (GAS-A forward: 5'-ACGTGTCCCCAGCTCTTCCCA-3', and reverse: 5'-TGCTCCAAGCCCTGTCCGAT3'; GAS-B forward: 5' -TGCTGTGAGCGCATACGAGAAA-3', and reverse: $5^{\prime}$-AAACCGTCTTCCCGTAAGCCAA-3'), the mouse Alb promoter (forward: 5'-TGGGAAAACTGGGAAAACCATC-3', and reverse: 5'-CACTCTCACACATACACTCCTGCTG- $3^{\prime}$ ).

\section{Mouse experiments}

Floxed Stat5 mice were a generous gift from Dr Lothar Hennighausen (National Institute of Health, USA) (Lee et al. 2007). Tamoxifen-inducible islet-specific Stat5 knockout mice were generated by crossing $P d x 1$-Cre-ER mice with floxed Stat5 mice (Lee et al. 2007). Tamoxifen (75 mg/kg body weight) or corn oil was injected intraperitoneally into 6-week-old mice. These mice were mated at 12 weeks old, and sacrificed at G12.5. After perfusion with $4 \%(\mathrm{w} / \mathrm{v})$ paraformaldehyde, pancreata were isolated from the mice and embedded in paraffin. Immunofluorescent staining was performed using an anti-5-HT antibody (1:1000, Immunostar, Hudson, WI, USA), an anti-Ki-67 antibody (1:200, BD Biosciences, Tokyo, Japan), and an anti-insulin antibody (1:1000 dilution, Dako, Tokyo,

Published by Bioscientifica Ltd. 

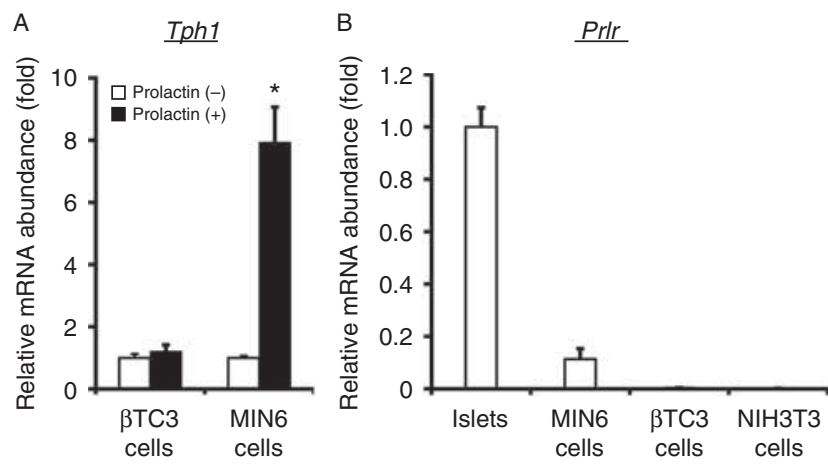

Figure 1

Prolactin induces the expression of Tph1 in MIN6 insulinoma cells. (A) $\beta$ TC3 cells and MIN6 cells were incubated with $44.2 \mathrm{nM}$ of prolactin for $24 \mathrm{~h}$. Tph1 expression was evaluated by qRT-PCR and normalized to Tbp expression $(n \geq 3)$. ${ }^{*} P<0.05$ compared with cells treated without prolactin. (B) Expression of Prlr in mouse islets, MIN6 cells, $\beta$ TC3 cells, and NIH3T3 cells was evaluated by qRT-PCR and normalized to Tbp expression $(n \geq 3)$. Results are shown as the means \pm S.E.M.

Japan) as described previously (Kim et al. 2010). Primary antibodies were detected with Alexa-fluor 488- and 555conjugated secondary antibodies and visualized using TCS-SP5 (Leica, Tokyo, Japan) and the Leica application Suite Version 2.6.0 software. Animal experiments were performed with the approval of the Ethics Review Committee for Animal Experimentation of Juntendo

$\mathrm{B}$
University and Korea Advanced Institute of Science and Technology.

\section{Statistical analysis}

All data are presented as the means \pm s.E.m. The Student's $t$-test was used for comparisons involving two conditions. One-way ANOVA followed by the Tukey-Kramer test, or two-way ANOVA was used for comparisons among more than three groups. $P<0.05$ was considered to indicate a statistically significant difference between two groups.

\section{Results}

\section{Prolactin-induced $T p h 1$ expression in the mouse insulinoma cell line MIN6}

As the first step toward investigating the mechanisms of Tph1 expression in $\beta$ cells, we evaluated the prolactininduced expression of Tph1 in mouse insulinoma cell lines MIN6 and $\beta$ TC3. In MIN6 cells, prolactin induced an eightfold increase in expression of Tph1 mRNA (Fig. 1A). On the other hand, although $\beta \mathrm{TC} 3$ cells also expressed Tph1 mRNA, prolactin did not alter its expression. Thus, we used MIN6 cells to investigate prolactin-responsive Tph1 expression. It is of note that the expression level of the
A

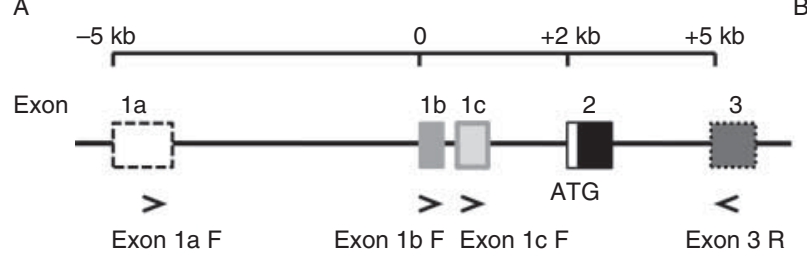

Exon 1a F Exon 1b F Exon 1c F Exon 3 R

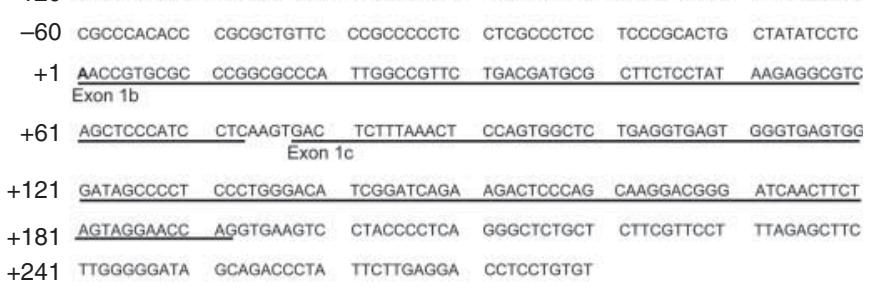

D

C

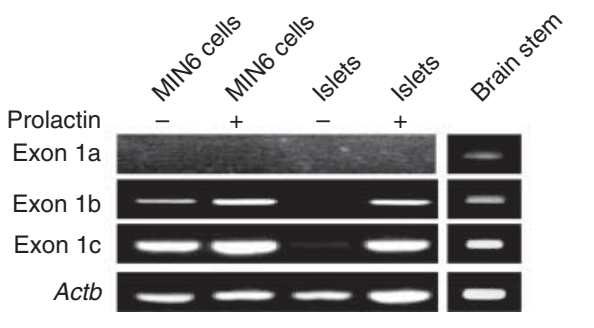

Figure 2

Exon $1 \mathrm{~b}$ and exon $1 \mathrm{c}$ exhibit $\beta$-cell-specific transcriptional activity of Tph1. $5^{\prime}$-RACE was performed using total RNA isolated from MIN6 cells to identify the $\beta$-cell-specific transcription start site for Tph1. (A) Diagram of the structure of the $T p h 1$ gene. Arrows indicate the location of the primers used to amplify each exon $1 . F$, forward primer; $R$, reverse primer. (B) Sequences of the $\beta$-cell-specific transcription start site, exon $1 \mathrm{~b}$ and exon 1c. The transcription start site for exon $1 \mathrm{~b}$ is set as +1 . (C) Total RNA

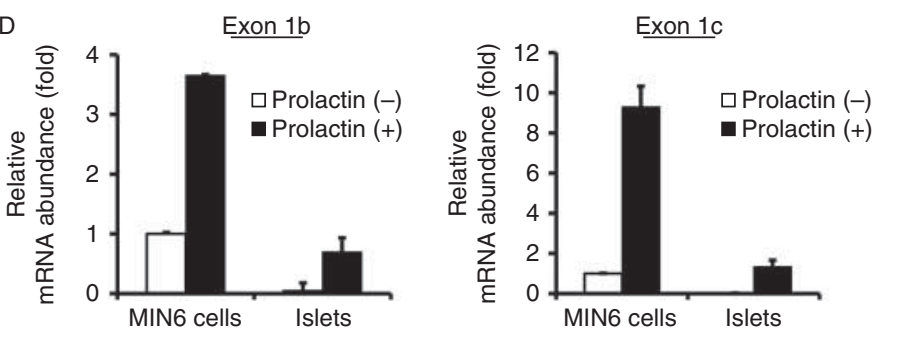

was isolated from MIN6 cells and mouse islets treated with or without $44.2 \mathrm{nM}$ of prolactin. Reverse transcribed cDNA was amplified using each exon 1 primer set as indicated in A. Mouse brain stem was used as positive control for each exon 1. (D) Amounts of cDNA transcribed from exon $1 \mathrm{~b}$ and exon 1c were evaluated by qRT-PCR and normalized to Tbp expression $(n \geq 3)$. Results are shown as the means \pm S.E.M.

Published by Bioscientifica Ltd. 
A

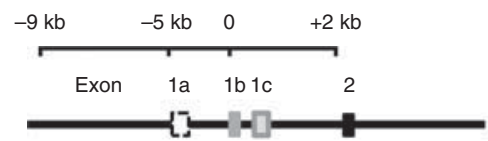

$-1155 \sim+2146$ bp

$-754 \sim+2146 \mathrm{bp}$

$+256 \sim+2146$ bp

$+646 \sim+2146$ bp

$-9196 \sim-5083 \mathrm{bp}$

$-8655 \sim-5083 \mathrm{bp}$

$-5670 \sim-5083 \mathrm{bp}$
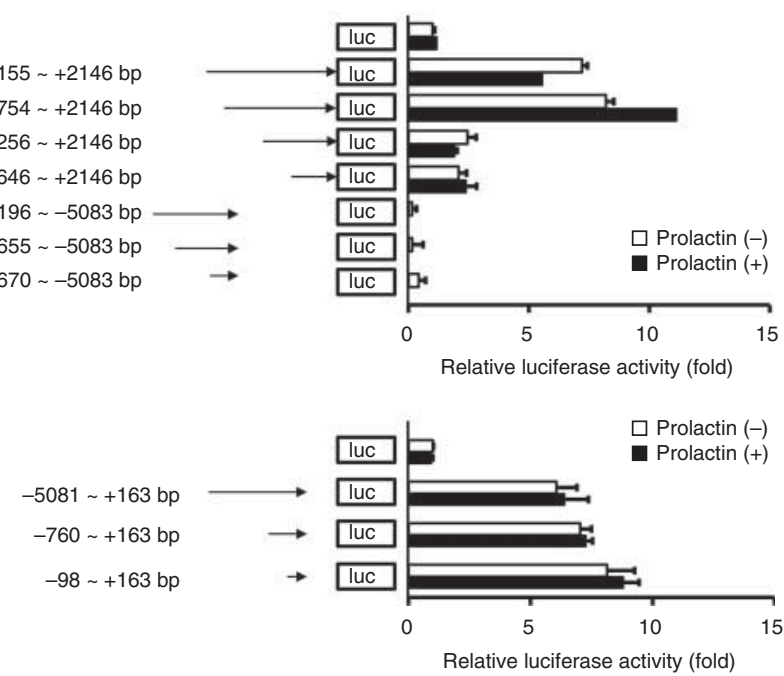

Figure 3

Reporter gene plasmid containing the $5^{\prime}$ flanking region of exon $1 \mathrm{~b}$ and exon 1c demonstrates transcriptional activity, but not prolactin responsiveness in MIN6 cells. Reporter gene plasmids were constructed containing various-length fragments of the mouse Tph1 gene, as indicated in A and B, and then transfected into MIN6 cells. At $24 \mathrm{~h}$ after transfection, MIN6 cells were treated with or without $44.2 \mathrm{nM}$ of prolactin for $24 \mathrm{~h}$ and then harvested for the luciferase assay. Luciferase activity was standardized by protein concentration. Relative luciferase activities were calculated with the activity of cells transfected with the pGL3 plasmid alone treated without prolactin set as 1 in (A), and with the pFLO plasmid alone treated without prolactin set as 1 in (B). All experiments were repeated at least three times. All data are shown as the mean \pm s.E.M.

prolactin receptor was $\sim 100$ times lower in $\beta$ TC3 cells than in MIN6 cells (Fig. 1B). According to the NCBI database (http://www.ncbi.nlm.nih.gov/), the mouse Tph1 gene has at least two alternatively spliced exon $1 \mathrm{~s}$ (shown as exon $1 \mathrm{a}$ and exon 1c in Fig. 2A). To identify the Tph1 gene transcripts that are expressed in $\beta$ cells, we performed 5'-RACE using RNA isolated from MIN6 cells, and found a transcript encoding another form of exon 1 located between 2 exons (shown as exon $1 \mathrm{~b}$ in Fig. $2 \mathrm{~A}$ and $\mathrm{B}$ ). Using primers to identify the expression of transcripts encoding each exon 1 (1a, 1b, and 1c), we performed RT-PCR (Fig. 2A). In MIN6 cells and islets, expression of transcripts encoding exon $1 b$ and $1 c$, but not that encoding exon 1a were observed and the expression of both of these transcripts was increased by prolactin (Fig. 2C and D).

To investigate whether the proximal 5'-flanking region of each exon contains promoter activity, we cloned various lengths of the $5^{\prime}$-flanking region of exon $1 \mathrm{a}$, and exon $1 b+1 c$, and inserted them upstream of the firefly luciferase gene in a reporter gene construct (Fig. 3A and B). After transfection of a series of constructs in MIN6 cells, we evaluated their transcriptional activity by the luciferase assay and found that the plasmids containing the $5^{\prime}$ flanking region of exon $1 b+1 c$ have promoter activity in MIN6 cells, but the plasmids containing the $5^{\prime}$-flanking region of exon 1a did not show any promoter activity (Fig. 3A). However, stimulation with prolactin did not increase the promoter activity of any of the constructs that we generated (Fig. 3A and B). These results suggest that prolactin responsive elements are not located in the proximal $5^{\prime}$-flanking region of exon $1 b+1 c$.

\section{Prolactin-induced expression of Tph1 is disrupted by treatment with a JAK2 inhibitor}

Reporter gene analyses have suggested that prolactinresponsive elements are located at a distal region from the transcription start site. Thus, we next analyzed the signaling pathway that is essential for prolactin-responsive Tph1 expression. Prolactin binds the prolactin receptor and drives several downstream protein kinase cascades, such as Jak2, Erk, and PI3K (Buchanan \& Xiang 2005, Bernichtein et al. 2010). After pretreatment with an inhibitor for each cascade, we treated MIN6 cells with or without prolactin and evaluated Tph1 expression by quantitative RT-PCR (qRT-PCR). The prolactin-induced expression of Tph1 was greatly reduced by treatment with the Jak2 inhibitor AG490 and partially reduced by the selective MEK1/2 inhibitor U0126 (Fig. 4A). On the other

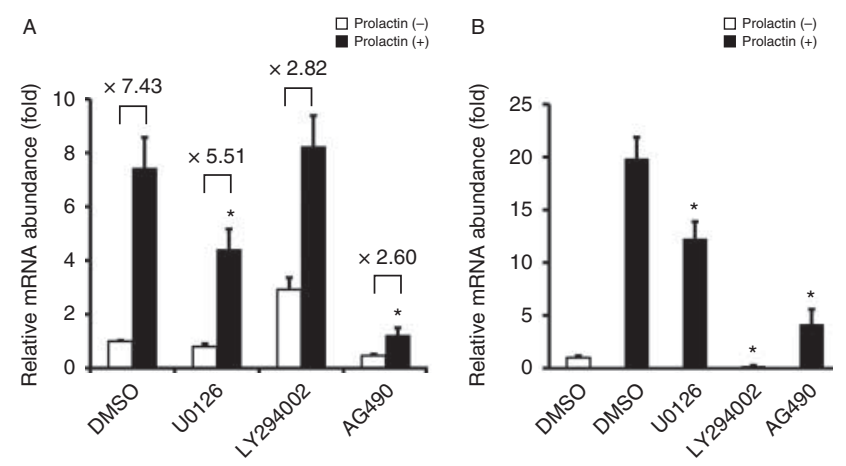

\section{Figure 4}

Prolactin-induced expression of Tph 1 is inhibited by treatment with prolactin receptor signaling inhibitors. (A) MIN6 cells were treated with $44.2 \mathrm{nM}$ of prolactin for $24 \mathrm{~h}$ in the presence or absence of $10 \mu \mathrm{M} \cup 0126$, $50 \mu \mathrm{M} \mathrm{LY} 294002$, or $100 \mu \mathrm{M} \mathrm{AG490}(n \geq 3)$. (B) Mouse islets were treated with or without $44.2 \mathrm{nM}$ of prolactin for $24 \mathrm{~h}$ in the presence of each of the inhibitors $(n=3)$. Tph1 expression was evaluated by qRT-PCR and normalized to $T b p$ expression. ${ }^{\star} P<0.05$ compared with cells treated with prolactin in the absence of inhibitors. Results are shown as the means \pm S.E.M.

Published by Bioscientifica Ltd. 

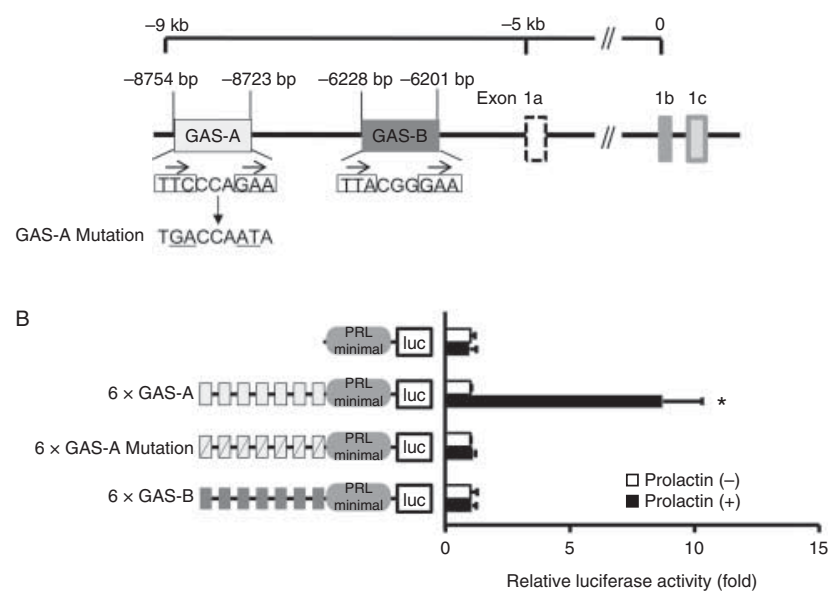

C

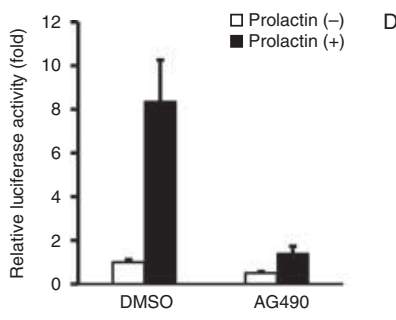

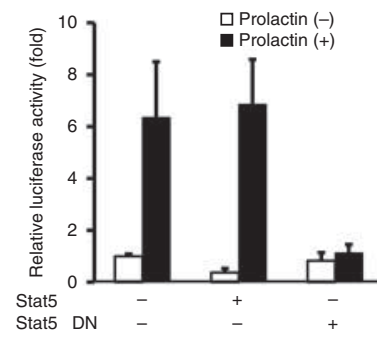

E

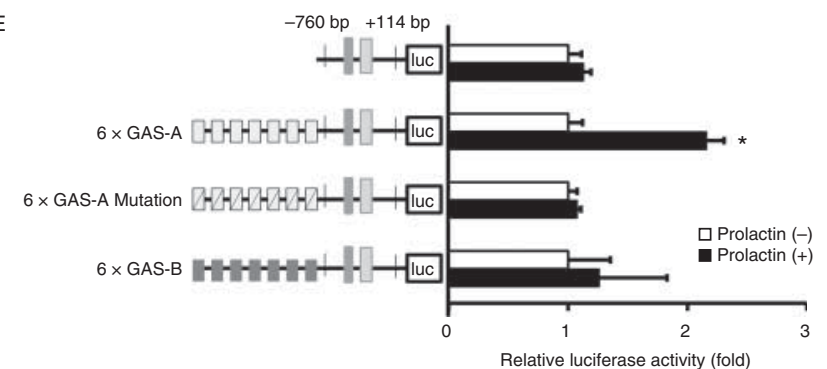

\section{Figure 5}

Putative interferon- $\gamma$-activated sequence shows prolactin responsiveness in MIN6 cells. (A) Diagram of the mouse Tph1 gene. Potential binding sites for Stat 5 are shown as GAS-A and GAS-B. Mutated GAS-A sequences are indicated by underlines. (B) Reporter gene plasmids with $6 \times$ GAS-A, $6 \times$ GAS-A Mutation, or the $6 \times$ GAS-B fragment inserted upstream of the heterologous prolactin minimal promoter were transfected into MIN6 cells. At $24 \mathrm{~h}$ after transfection, MIN6 cells were treated with or without $44.2 \mathrm{nM}$ of prolactin for $24 \mathrm{~h}$, and harvested for the luciferase assay. (C) The $6 \times$ GAS-A plasmid was transfected into MIN6 cells. At $24 \mathrm{~h}$ after transfection, MIN6 cells were treated with or without $44.2 \mathrm{nM}$ of prolactin in the presence or absence of $100 \mu \mathrm{M}$ AG490 for $24 \mathrm{~h}$. (D) Plasmids encoding

hand, addition of the PI3K inhibitor LY294002 increased the basal expression of Tph1; however, its expression was not altered upon treatment with prolactin, and hence resulted in decreased prolactin responsiveness. We also evaluated the effect of these inhibitors on isolated mouse islets treated with prolactin and found that Tph1 expression was attenuated by treatment with the MEK1/2 inhibitor, the PI3K inhibitor, or the JAK2 inhibitor (Fig. 4B). These data suggest that each pathway contributes to prolactin-induced Tph1 expression in mouse islets. As activation of Jak2 plays a central role in Tph1 expression in MIN6 cells as well as in mouse islets, we further investigated the Jak2/Stat 5 pathway. The prolactin receptor activates Jak2, which induces the phosphorylation and dimerization of Stat5 (Sorenson \& Brelje 2009, Binart et al. 2010). Dimerized Stat5 translocates from the cytosol into the nucleus and recognizes interferon $\gamma$-activated sequence (GAS) (Berg 2008, Muller et al. 2008). Therefore, we surveyed the GAS consensus sequence in the $5^{\prime}$-flanking region of the Tph1 gene and found two sequences that perfectly match the GAS consensus sequence (GAS-A and GAS-B shown in
Stat5A or a dominant-negative form of Stat5A were co-transfected with the $6 \times$ GAS-A plasmid into MIN6 cells. At $24 \mathrm{~h}$ after transfection, MIN6 cells were treated with or without $44.2 \mathrm{nM}$ of prolactin for $24 \mathrm{~h}$. (E) The reporter gene plasmids containing a fragment from $-760 \mathrm{bp}$ to $+114 \mathrm{bp}$ of the Tph1 gene linked to the $6 \times$ GAS-A, $6 \times$ GAS-A Mutation, or the $6 \times$ GAS-B fragment were transfected into MIN6 cells. At $24 \mathrm{~h}$ after transfection, the cells were incubated with or without $44.2 \mathrm{nM}$ of prolactin for $24 \mathrm{~h}$ and harvested. Luciferase activity was standardized by the protein concentration. Luciferase activity in cells without prolactin treatment was set as 1 . $* P<0.05$ compared with cells treated without prolactin. All experiments were repeated at least three times. All data are shown as means \pm s.E.M.

Fig. 5A). These sequences are located at about 9 and $6 \mathrm{kbp}$ upstream of the transcription start site, respectively.

To investigate whether these potential Stat5 binding regions are sufficient to exhibit prolactin responsiveness, we analyzed reporter gene constructs containing each potential Stat 5 binding region upstream of a heterologous promoter, the prolactin minimal promoter. Transcriptional activity of the GAS-A plasmid, but not the GAS-B plasmid, was enhanced by treatment with prolactin in MIN6 cells (Fig. 5B). Insertion of mutations into the GAS-A sequences disrupted prolactin-induced transactivation of the GAS-A plasmid (Fig. 5B). Prolactin-induced transcriptional activity was disrupted by the forced expression of a dominant-negative form of Stat5A as well as by treatment with a Jak2 inhibitor (Fig. 5C and D). Furthermore, a reporter gene construct containing the $760 \mathrm{bp}$ upstream of the $5^{\prime}$-flanking region of exon $1 \mathrm{~b}$ showed prolactin responsiveness upon insertion of the GAS-A sequence, but not the GAS-B nor the mutated GAS-A sequence (Fig. 5E). These data support the idea that GAS-A is a functional prolactin-responsive element that is activated by Jak2 and Stat5. http://jme.endocrinology-journals.org DOI: 10.1530/JME-14-0299
(C) 2015 Society for Endocrinology Printed in Great Britain 
A
GAS-A probe
5'-GATCTGTCCCCAGCTCITCCCAGAAAGCCCTGAGGTG-3'
GAS cold probe
5'-CTGTCGTITCCTGGAATTGGCCATACCTGGAAGAGGCC-3
GAS-A mutation probe
5'-GATCTGTCCCCAGCTCTGACCAATAAGCCCTGAGGTG-3'

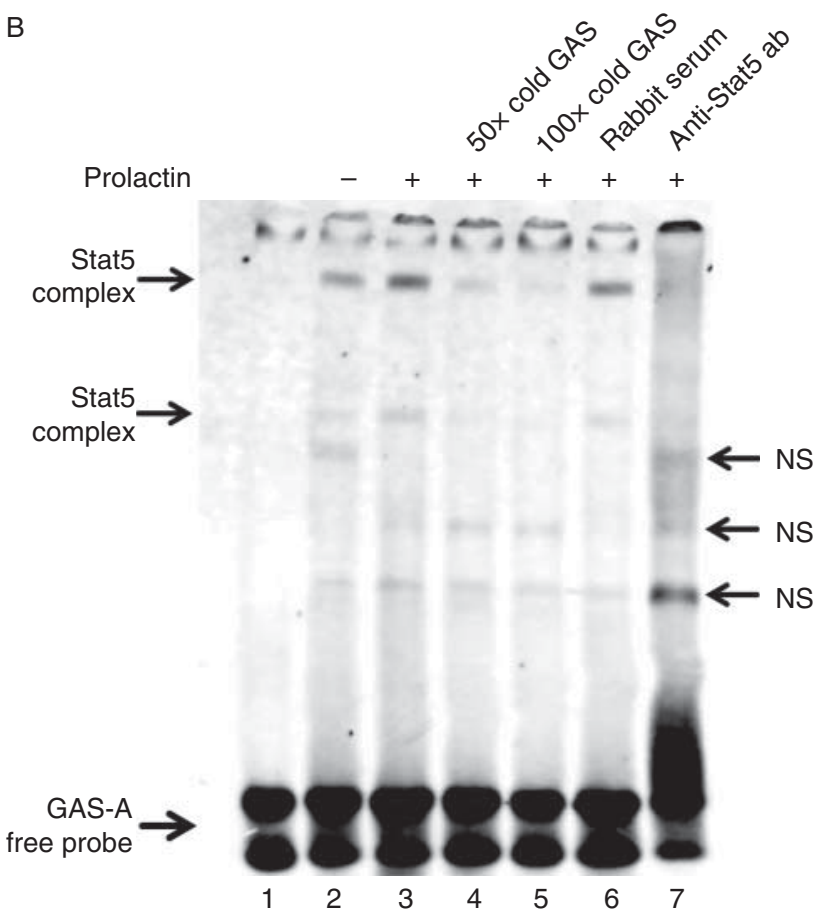

C

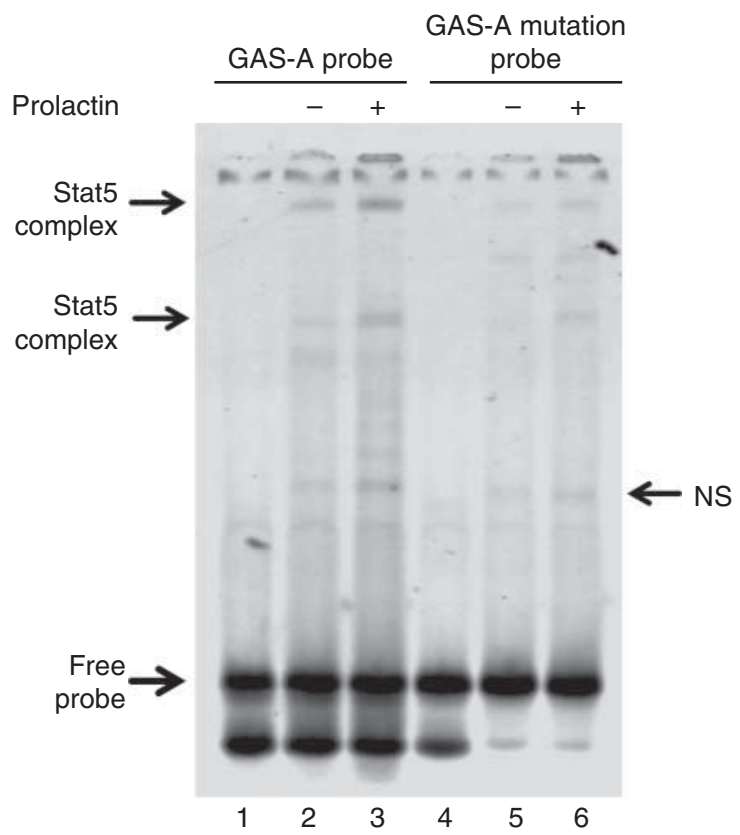

http://jme.endocrinology-journals.org DOI: 10.1530/JME-14-0299

\section{Stat5 binds a potential Stat5 binding region in the Tph1 gene}

To investigate the prolactin-responsive binding of Stat 5 to GAS-A, we isolated nuclear proteins from MIN6 cells and performed the EMSA using sequences of the GAS-A region as a probe. The GAS-A probe identified several nuclear proteins, and the amount of these nuclear proteins bound to the GAS-A probe further increased by treatment with prolactin (Fig. 6A and B). The cold probe of the consensus sequence for GAS (Soldaini et al. 2000) disrupted the association between the GAS-A probe and the nuclear proteins that were recognized by the anti-serum for Stat 5 . On the other hand, the mutated GAS-A probe did not efficiently recognize Stat5 (Fig. 6C). Next, we designed primers recognizing the GAS-A region and performed the ChIP assay using anti-serum for Stat5 (Fig. 7A). Prolactin treatment enhanced the enrichment of Stat5 in the GAS-A region of MIN6 cells as well as of isolated mouse islets (Fig. 7B). In addition, we performed ChIP analysis in islets isolated from pregnant mice and found that Stat5 recognized the GAS-A region in mouse islets during pregnancy (Fig. 7B). As there are no GAS consensus sequences except the GAS-A sequence around this region, our results suggest that Stat5 binds to the GAS-A site in islets during pregnancy.

\section{Prolactin increases the transcriptional activity of Stat5 through Erk and PI3K}

Recently, prolactin was reported to enhance the transactivation activity of Stat5 after inducing the binding of dimerized Stat5 to GAS (Moriggl et al. 1996). Therefore, we generated a plasmid encoding Stat5A conjugated with the DNA-binding domain (DBD) of GAL4, and cotransfected this with a reporter gene construct containing GAL4

\section{Figure 6}

Putative interferon- $\gamma$-activated sequence identifies Stat5. (A) Sequences of the IR Dye-labeled probes and non-labeled cold probe. (B) Electrophoretic mobility shift assays (EMSAs) were performed using nuclear extracts from MIN6 cells treated with or without $44.2 \mathrm{nM}$ of prolactin for $1 \mathrm{~h}$. Nuclear protein-DNA complexes were resolved in $5 \%$ non-denaturing polyacrylamide gels (lanes $2-3$ ). Competition assays were performed in the presence of a 50 -fold or 100-fold molar excess of the GAS consensus sequences (lanes 4-5). The supershift assay was performed in the presence of rabbit serum (lane 6) and STAT5 antibody (lane 7). (C) Binding activity of the GAS-A probe (lanes 1-3) and the GAS-A Mutation probe (lanes 4-6) were evaluated using nuclear extracts from MIN6 cells. All experiments were repeated at least three times. 'Stat 5 complex' indicates the protein and probe complex, including Stat5. 'NS' indicates a non-specific band.

Published by Bioscientifica Ltd. 
A
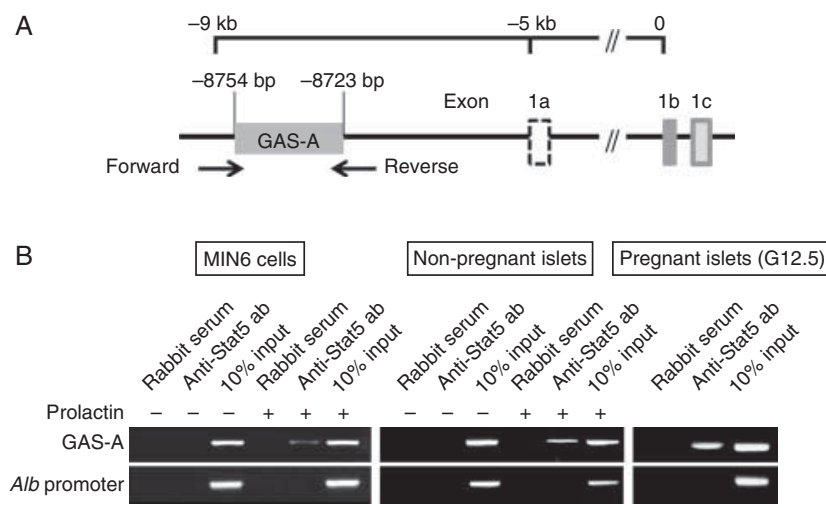

Figure 7

Stat 5 binds to the GAS-A region in MIN6 cells and isolated mouse islets. Chromatin immunoprecipitation analysis was performed to demonstrate binding of Stat5 on the Tph1 promoter in MIN6 cells and mouse islets. (A) Diagram of the region in the Tph1 locus amplified by PCR. (B) MIN6 cells and isolated mouse islets were treated with or without $44.2 \mathrm{nM}$ of prolactin for $1 \mathrm{~h}$. Pregnant mouse islets were isolated at G12.5. Cross-liked proteinDNA complexes were immunoprecipitated with the anti-Stat5 antibody or normal rabbit IgG used as a non-specific control. Input DNA was determined using $10 \%$ of the total sample as the template. The proximal promoter region of the $A / b$ gene was used as a negative control. All experiments were repeated at least three times.

binding sequences (upstream activating sequences of galactose (UASG)) into MIN6 cells. Forced expression of GAL4 DBD-Stat5A increased luciferase activity to a higher level than forced expression of the GAL4 DBD, suggesting the existence of the transactivation activity of Stat5A (Fig. 8A). Treatment with prolactin further enhanced the transactivation activity of Stat5A in MIN6 cells, and its activity was partially attenuated by pretreatment with an MEK1/2 inhibitor or a PI3K inhibitor, but not a Jak2 inhibitor (Fig. 8B). These results suggest that the Erk and PI3K pathways partially regulate prolactin-induced Stat5 transcriptional activity.

\section{Serotonin expression is decreased in islets of $\beta$-cell specific Stat5-deficient mice}

To confirm the contribution of Stat5 on Tph1 expression in islets, we generated tamoxifen-inducible $\beta$-cell specific Stat5-deficient mice ( $\beta$-Stat $5 \mathrm{~K} / \mathrm{O})$ by crossing mice expressing tamoxifen-inducible Cre driven by the mouse $P d x 1$ promoter and mice with floxed Stat5. After the injection of tamoxifen or corn oil, $\beta$-Stat $5 \mathrm{~K} / \mathrm{O}$ mice were mated, and the pancreata of the resulting pregnant mice were isolated at G12.5. Immunohistochemical analysis was then performed to evaluate the expression of 5-HT in the isolated islets. Stat5 inactivation led to a decrease in the expression of 5-HT in islets, which was accompanied with decreases in the percentage of Ki-67-positive cells among insulin-positive cells (Fig. 9A and B).

\section{Discussion}

Pregnancy greatly alters hormonal release patterns, causing physiological changes including insulin resistance. The insufficient compensation of insulin secretion contributes to the development of gestational diabetes. Meanwhile, numerous studies performed in pregnant mice have shown that proliferation of $\beta$ cells is augmented in response to pregnancy (Zhang et al. 2010, Demirci et al. 2012, Jacovetti et al. 2012). The prolactin receptor is the target of prolactin and placental lactogen, and is expressed in pancreatic $\beta$ cells to contribute for augmentation of insulin release during pregnancy (Buchanan \& Xiang 2005). Although overnutrition also causes insulin resistance and an increase in islet mass, the mechanism of the $\beta$-cell proliferation is thought to be different from that which occurs during pregnancy. Pregnancy augments the

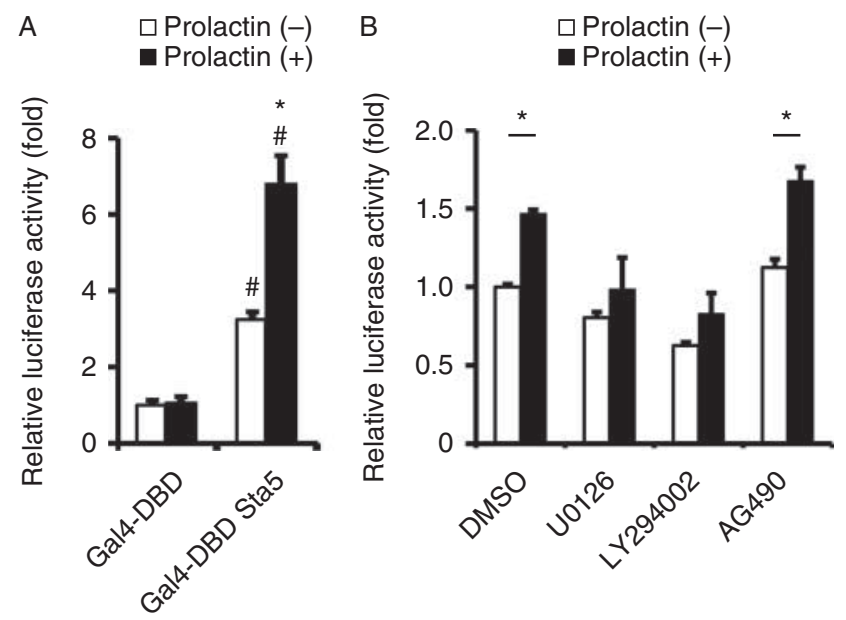

\section{Figure 8}

Prolactin enhances the transactivation of Stat5A in MIN6 cells. (A) One microgram of UAS-TATA-Luciferase was cotransfected with $0.2 \mu \mathrm{g}$ of the expression plasmid encoding GAL4-DBD or the GAL4 DBD-Stat5A fusion protein into MIN6 cells. At $24 \mathrm{~h}$ after transfection, the cells were incubated with or without $44.2 \mathrm{nM}$ of prolactin. At $48 \mathrm{~h}$ after transfection, cells were harvested and the luciferase assay was performed. Relative luciferase activities were calculated with the activity of the cells transfected with pGAL4-DBD without prolactin treatment set as 1. (B) At 30 min after preincubation with $10 \mu \mathrm{M}$ U0126, $50 \mu \mathrm{M}$ LY294002, or $100 \mu \mathrm{M}$ AG490, MIN6 cells were treated with or without $44.2 \mathrm{nM}$ of prolactin. The luciferase activity was standardized by the protein concentration. Relative luciferase activities were calculated with the activity of the cells transfected with pGAL4 DBD-Stat5A without prolactin treatment set as $1 .{ }^{\#} P<0.05$ compared with cells transfected with pGAL4-DBD in the absence of prolactin; ${ }^{*} P<0.05$ compared with cells transfected with pGAL4 DBDStat5A in the absence of prolactin. Experiments were repeated at least four times. All data are shown as means \pm s.E.M.

Published by Bioscientifica Ltd. 


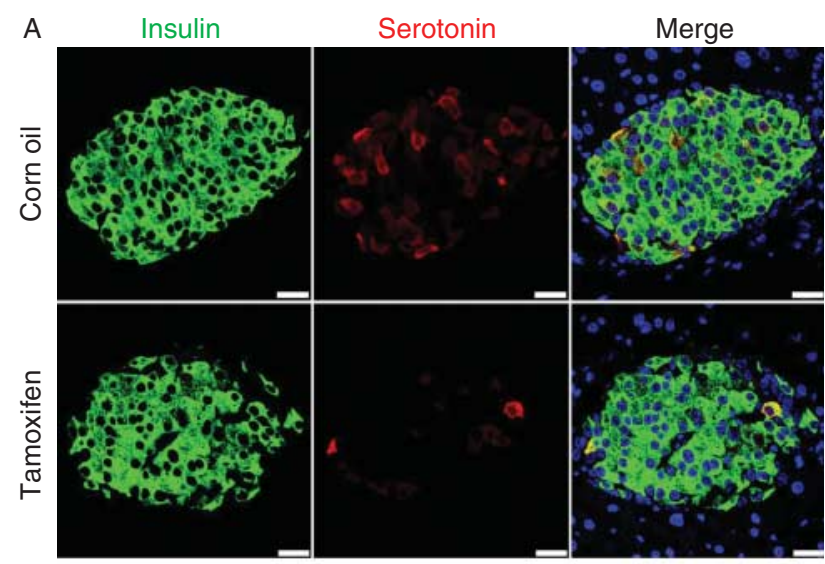

Scale bar: $25 \mu \mathrm{m}$

B

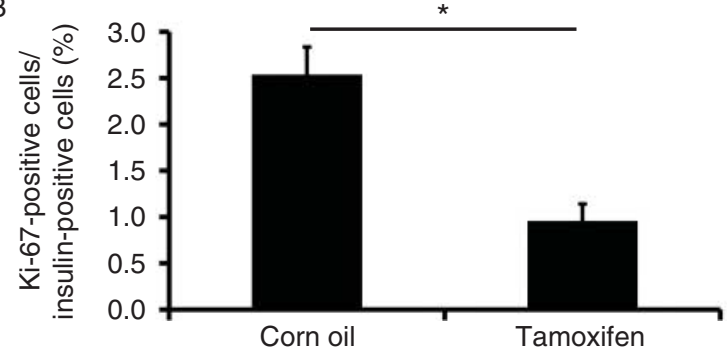

Figure 9

5 -HT expression is reduced in islets of $\beta$-cell specific Stat 5 knockout mice. Tamoxifen-inducible $\beta$-cell specific Stat 5 knockout mice $(P d \times 1$-Cre-ER mice $\times$ floxed Stat 5 mice) were treated with tamoxifen or corn oil at 6 weeks of age and were mated at 12 weeks of age. Their pancreata were isolated at G12.5. (A) Immunofluorescent staining was performed in pancreatic sections (green: insulin; red: 5-HT; blue: DAPI). (B) The percentage of Ki-67-positive cells per insulin-positive cells was calculated. Approximately $1-2 \times 10^{3}$ insulin-positive cells were counted in 1 or 2 pancreatic sections of both the tamoxifen-injected group $(n=8)$ and the corn-oil-injected group $(n=5)$. ${ }^{*}>0.05$ compared with the corn-oilinjected group. All data are shown as means \pm s.E.M.

secretion of various hormones that may regulate $\beta$-cell function or survival, such as estrogen, placental lactogen, and prolactin. Previously, our group showed that prolactin increases the expression of the rate-limiting enzyme for 5-HT synthase, Tph1, and that 5-HT contributes to the increase in $\beta$-cell mass through upregulation of Ccna1, Conb1, and Ccnb2 (Kim et al. 2010).

In this study, we identified the $\beta$-cell-specific transcriptional start site of $T p h 1$ as exon $1 b$ and exon $1 c$, and evaluated the precise mechanisms of prolactin-responsive Tph1 expression by reporter gene analysis. Whereas proximal 5 '-flanking regions of exon $1 \mathrm{~b}$ and exon $1 \mathrm{c}$ exhibited promoter activity in $\beta$-cells, they did not show prolactin responsiveness. Because prolactin-induced transcription of $T p h 1$ was greatly disrupted by treatment with a Jak2 inhibitor in MIN6 cells as well as mouse islets, we analyzed potential GAS regions in the $5^{\prime}$-flanking region of exon $1 \mathrm{~s}$ and identified the GAS-A region located $9 \mathrm{~kb}$ upstream of exon $1 \mathrm{~b}$. The GAS-A region exhibited prolactin responsiveness and was recognized by Stat5 in MIN6 cells. We did not detect the expression of mRNA containing exon 1a in MIN6 cells or in mouse islets. Consistent with the results of RT-PCR analysis, the luciferase activity of reporter gene plasmids containing the $5^{\prime}$-flanking region of exon $1 \mathrm{a}$ was repressed compared to that of the control reporter vector, suggesting that repressors might block the transcriptional activity of exon $1 \mathrm{a}$ in $\beta$ cells. Although the reporter gene constructs containing the $5^{\prime}$-flanking region of exon 1a have the GAS-A region, they failed to respond to prolactin (Fig. 3A). We speculated that this was due to the binding of repressor proteins to these constructs.

To evaluate the GAS-A region in islets, we performed ChIP analysis using isolated mouse islets, and demonstrated that prolactin induced Stat5 binding on GAS-A region and that Stat 5 recognized the GAS-A region in islets isolated from pregnant mice. Furthermore, we analyzed the pancreata of $\beta$-cell-specific Stat5 knockout mice that were shown to exhibit glucose intolerance (Lee et al. 2007). During pregnancy, $\beta$-cell-specific Stat5 knockout mice demonstrated decreases of 5-HT expression and decreases in the number of Ki-67-positive cells in islets. Our results suggest that a reduction of 5-HT expression may contribute to the glucose intolerance in $\beta$-cell-specific Stat 5 knockout mice.

Prolactin induces the phosphorylation and dimerization of STAT5, which increases the binding activity of STAT5 on GAS (Karnik et al. 2007, Qian et al. 2009). Although the C-terminal domain of Stat5 is not sufficient for the DNA binding of dimerized Stat5, it still contributes to the enhancement of transactivation in response to prolactin or growth hormone (GH) (Moriggl et al. 1996). To assess the transactivation activity of Stat5, we generated the fusion protein GAL4 DBD-Stat5A and evaluated its transcriptional activity using a reporter gene plasmid containing UASG. GAL4 DBD-Stat5A bound UASG, and treatment with prolactin further enhanced the luciferase activity in MIN6 cells. Our results indicate that prolactin augments the transcriptional activity of Stat5 through increases of both DNA binding and transactivation activity in $\beta$ cells.

Previous studies showed several mechanisms of transactivation in the C-terminal domain of Stat5. Disruption of serine phosphorylation in the C-terminal domain of Stat5 impairs prolactin and GH responsiveness (Yamashita et al. 1998, Park et al. 2001). Nonacidic residues of the C-terminal domain contribute to prolactin responsiveness in NIH3T3

Published by Bioscientifica Ltd 


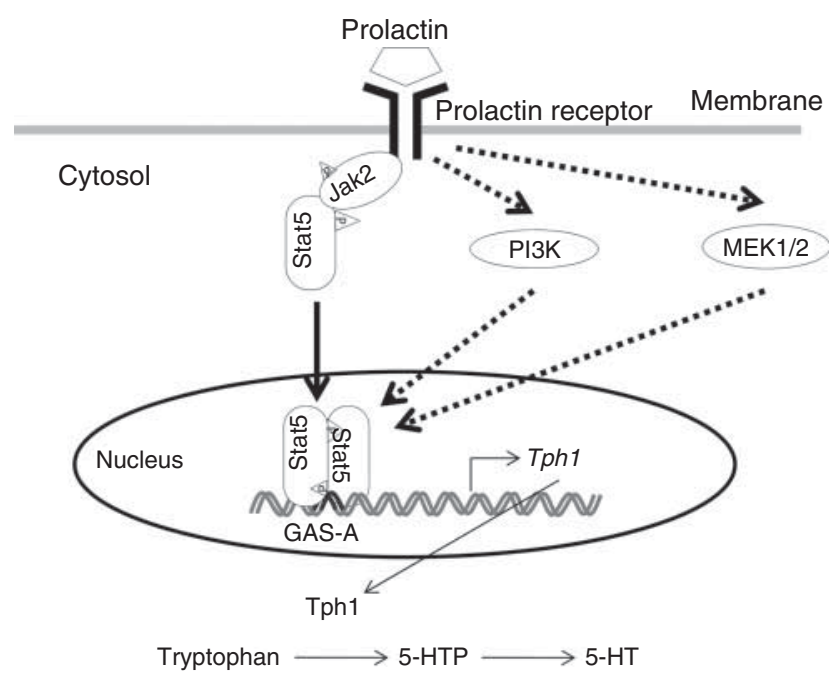

\section{Figure 10}

Proposed model of 5-HT synthesis in response to prolactin in $\beta$ cells during pregnancy. Prolactin binds to its receptor on $\beta$ cells, which induces the phosphorylation of Jak2 and Stat5. The dimerized Stat5 is translocated into the nucleus and binds to the GAS-A region in the Thp1 promoter to induce $T p h 1$ expression. Stat5-induced Tph1 expression is partially mediated by Erk and PI3K in response to prolactin. Tph1 is the rate-limiting enzyme for the synthesis of $5-\mathrm{HT}$ that contributes to $\beta$-cell proliferation during pregnancy. 5-HTP, 5-hydroxytryptophan.

cells (Callus \& Mathey-Prevot 2000). Litterst et al. (2003) demonstrated that an interaction between the C-terminal domain and a cofactor is important for prolactin-induced $\beta$-casein expression in HeLa cells. However, the upstream cascade of the C-terminal domain of Stat5 is not clear. Our qRT-PCR analysis showed that pretreatment with an MEK1/2 inhibitor or PI3K inhibitor partially impairs prolactin responsiveness in Tph1 expression. Reporter gene analysis using GAL4 DBD-Stat5 demonstrated that prolactin-induced enhancement of the transactivation of Stat 5 was disrupted by treatment with an MEK1/2 inhibitor or PI3K inhibitor, but not with a Jak2 inhibitor. These results suggest that the Erk and PI3K cascades enhance the transactivation of Stat 5 in $\beta$ cells (Fig. 10). Schraenen et al. (2010) showed that treatment with an MEK1/2 inhibitor or PI3K inhibitor did not impair prolactin-induced Tph1 expression in MIN6 cells. MIN6 cells are heterogeneous and can be subcloned into several populations with slightly different characteristics (Lilla et al. 2003, Yamato et al. 2013). The discrepancy between our results and those of Schraenen et al. might hence be a result of using different subclones of MIN6 cells, in which the expression profiles of cofactors may differ. Therefore, the signaling cascade that utilizes Erk or PI3K appears to contribute to the prolactininduced enhancement of Stat5 transactivation in the
MIN6 cell subclone that was used in our present study, and importantly, in mouse islets. Further experiments should be performed to address the relationship between the Stat5, Erk, and PI3K pathways for Tph1 expression.

Satyanaryana et al. showed that several GASs are located around the $I g f 1$ gene and regulate the expression of $I g f 1$ in response to GH, suggesting that multiple GASs may contribute to Tph1 expression in islets (Eleswarapu et al. 2008). The recently developed tool for ChIP analysis linked to next-generation DNA sequencing should allow us to identify numerous cis-elements in the whole genome. This technique should provide more comprehensive data on the role of Stat5 in Tph1 expression, as well as comprehensive information on the mechanism by which prolactin regulates the compensation of $\beta$ cells during pregnancy. Further studies are required to fully clarify the role of 5-HT in $\beta$-cell proliferation, which should contribute to developing new strategies to increase $\beta$-cell mass for the treatment of type 1 as well as type 2 diabetes.

\section{Supplementary data}

This is linked to the online version of the paper at http://dx.doi.org/10.1530/ JME-14-0299.

Declaration of interest

H W has received lecture fees from Astellas Pharma, AstraZeneca, Boehringer Ingelheim, Daiichi Sankyo, Inc., Eli Lilly and Company, Kissei Pharmaceutical Co., Kowa Pharmaceutical Co., Kyowa Hakko Kirin Co., MSD (Merck Sharp and Dohme), Novartis Pharmaceuticals, Novo Nordisk Pharma, Ono Pharmaceutical Co., Mitsubishi Tanabe Pharma, SanofiAventis, Sanwakagaku Kenkyusho, and Takeda Pharmaceutical Co., and research funds from Astellas Pharma, AstraZeneca, Bristol-Myers Squibb, Boehringer Ingelheim, Daiichi Sankyo, Inc., Dainippon Sumitomo Pharma, Eli Lilly, Johnson and Johnson, Kissei Pharmaceutical Co., Kowa Pharmaceutical Co., Kyowa Hakko Kirin Co., MSD, Mitsubishi Tanabe Pharma, Mochida Pharmaceutical Co., Novartis Pharmaceuticals, Novo Nordisk Pharma, Pfizer, Sanwakagaku Kenkyusho, Sanofi-Aventis, and Takeda Pharmaceutical Co. Y F has received a lecture fee from Novartis and Eli Lilly, research funding from Novartis, MSD, and Takeda Pharmaceutical Company.

\section{Author contribution statement}

$\mathrm{T} \mathrm{O}, \mathrm{H} \mathrm{W}$, and $\mathrm{H} \mathrm{K}$ designed research; $\mathrm{H} \mathrm{I}, \mathrm{M} \mathrm{M}, \mathrm{A} \mathrm{H}, \mathrm{K} \mathrm{F}, \mathrm{Y} \mathrm{G} \mathrm{K}$, and $\mathrm{M}$ T conducted research; T O, H W, and $\mathrm{Y} \mathrm{F}$ analyzed the data; $\mathrm{TO}, \mathrm{HI}$, and $\mathrm{H} \mathrm{W}$ wrote the paper; $\mathrm{H} \mathrm{W}$ had primary responsibility for final content. All authors read and approved the final manuscript.

\section{Acknowledgements}

We thank Dr Lothar Hennighausen (National Institute of Health, USA) for providing the floxed Stat5 mouse. We thank Dr Shannon L Kelleher (Pennsylvania State University, USA) for providing plasmids encoding

Published by Bioscientifica Ltd 
Stat5A and Stat5A DN. We gratefully acknowledge Ms Naoko Daimaru and Ms Hiroko Hibino for assistance with the experiments.

\section{References}

Berg T 2008 Signal transducers and activators of transcription as targets for small organic molecules. Chembiochem 9 2039-2044. (doi:10.1002/cbic. 200800274)

Bernichtein S, Touraine P \& Goffin V 2010 New concepts in prolactin biology. Journal of Endocrinology 206 1-11. (doi:10.1677/JOE-10-0069)

Binart N, Bachelot A \& Bouilly J 2010 Impact of prolactin receptor isoforms on reproduction. Trends in Endocrinology and Metabolism 21 362-368. (doi:10.1016/j.tem.2010.01.008)

Buchanan TA \& Xiang AH 2005 Gestational diabetes mellitus. Journal of Clinical Investigation 115 485-491. (doi:10.1172/JCI200524531)

Butler AE, Janson J, Bonner-Weir S, Ritzel R, Rizza RA \& Butler PC 2003 $\beta$-cell deficit and increased $\beta$-cell apoptosis in humans with type 2 diabetes. Diabetes 52 102-110. (doi:10.2337/diabetes.52.1.102)

Callus BA \& Mathey-Prevot B 2000 Hydrophobic residues Phe751 and Leu753 are essential for STAT5 transcriptional activity. Journal of Biological Chemistry 275 16954-16962. (doi:10.1074/jbc.M909976199)

Chang-Chen KJ, Mullur R \& Bernal-Mizrachi E 2008 -cell failure as a complication of diabetes. Reviews in Endocrine \& Metabolic Disorders 9 329-343. (doi:10.1007/s11154-008-9101-5)

Deering TG, Ogihara T, Trace AP, Maier B \& Mirmira RG 2009 Methyltransferase Set7/9 maintains transcription and euchromatin structure at islet-enriched genes. Diabetes 58 185-193. (doi:10.2337/db08-1150)

Demirci C, Ernst S, Alvarez-PerezJC, Rosa T, Valle S, Shridhar V, Casinelli GP, Alonso LC, Vasavada RC \& Garcia-Ocana A 2012 Loss of HGF/c-Met signaling in pancreatic $\beta$-cells leads to incomplete maternal $\beta$-cell adaptation and gestational diabetes mellitus. Diabetes 61 1143-1152. (doi:10.2337/db11-1154)

Eleswarapu S, Gu Z \& Jiang H 2008 Growth hormone regulation of insulinlike growth factor-I gene expression may be mediated by multiple distal signal transducer and activator of transcription 5 binding sites. Endocrinology 149 2230-2240. (doi:10.1210/en.2007-1344)

Gregg BE, Moore PC, Demozay D, Hall BA, Li M, Husain A, Wright AJ, Atkinson MA \& Rhodes CJ 2012 Formation of a human $\beta$-cell population within pancreatic islets is set early in life. Journal of Clinical Endocrinology and Metabolism 97 3197-3206. (doi:10.1210/ jc.2012-1206)

Huang C, Snider F \& Cross JC 2009 Prolactin receptor is required for normal glucose homeostasis and modulation of $\beta$-cell mass during pregnancy. Endocrinology 150 1618-1626. (doi:10.1210/en.2008-1003)

Hughes E \& Huang C 2011 Participation of Akt, menin, and p21 in pregnancy-induced $\beta$-cell proliferation. Endocrinology 152 847-855. (doi:10.1210/en.2010-1250)

Iwashita N, Uchida T, Choi JB, Azuma K, Ogihara T, Ferrara N, Gerber H, Kawamori R, Inoue M \& Watada H 2007 Impaired insulin secretion in vivo but enhanced insulin secretion from isolated islets in pancreatic $\beta$ cell-specific vascular endothelial growth factor-A knock-out mice. Diabetologia 50 380-389. (doi:10.1007/s00125-006-0512-0)

Jacovetti C, Abderrahmani A, Parnaud G, Jonas JC, Peyot ML, Cornu M, Laybutt R, Meugnier E, Rome S, Thorens B et al. 2012 MicroRNAs contribute to compensatory $\beta$ cell expansion during pregnancy and obesity. Journal of Clinical Investigation 122 3541-3551. (doi:10.1172/JCI64151)

Karnik SK, Chen H, McLean GW, Heit JJ, Gu X, Zhang AY, Fontaine M, Yen MH \& Kim SK 2007 Menin controls growth of pancreatic $\beta$-cells in pregnant mice and promotes gestational diabetes mellitus. Science $\mathbf{3 1 8}$ 806-809. (doi:10.1126/science.1146812)

Kim H, Toyofuku Y, Lynn FC, Chak E, Uchida T, Mizukami H, Fujitani Y, Kawamori R, Miyatsuka T, Kosaka Y et al. 2010 Serotonin regulates pancreatic $\beta$ cell mass during pregnancy. Nature Medicine 16 804-808. (doi:10.1038/nm.2173)

Lee JY, Gavrilova O, Davani B, Na R, Robinson GW \& Hennighausen L 2007 The transcription factors $S t a t 5 a / b$ are not required for islet development but modulate pancreatic $\beta$-cell physiology upon aging. Biochimica et Biophysica Acta 1773 1455-1461. (doi:10.1016/j.bbamcr. 2007.05.010)

Lilla V, Webb G, Rickenbach K, Maturana A, Steiner DF, Halban PA \& Irminger JC 2003 Differential gene expression in well-regulated and dysregulated pancreatic $\beta$-cell (MIN6) sublines. Endocrinology 144 1368-1379. (doi:10.1210/en.2002-220916)

Litterst CM, Kliem S, Marilley D \& Pfitzner E 2003 NCoA-1/SRC-1 is an essential coactivator of STAT5 that binds to the FDL motif in the $\alpha$-helical region of the STAT5 transactivation domain. Journal of Biological Chemistry 278 45340-45351. (doi:10.1074/jbc.M303644200)

Meier JJ, Bhushan A, Butler AE, Rizza RA \& Butler PC 2005 Sustained $\beta$ cell apoptosis in patients with long-standing type 1 diabetes: indirect evidence for islet regeneration? Diabetologia 48 2221-2228. (doi:10.1007/s00125-005-1949-2)

Meier JJ, Butler AE, Saisho Y, Monchamp T, Galasso R, Bhushan A, Rizza RA $\&$ Butler PC $2008 \beta$-cell replication is the primary mechanism subserving the postnatal expansion of $\beta$-cell mass in humans. Diabetes 57 1584-1594. (doi:10.2337/db07-1369)

Moriggl R, Gouilleux-Gruart V, Jahne R, Berchtold S, Gartmann C, Liu X, Hennighausen L, Sotiropoulos A, Groner B \& Gouilleux F 1996 Deletion of the carboxyl-terminal transactivation domain of MGF-Stat5 results in sustained DNA binding and a dominant negative phenotype. Molecular and Cellular Biology 16 5691-5700.

Muller J, Sperl B, Reindl W, Kiessling A \& Berg T 2008 Discovery of chromone-based inhibitors of the transcription factor STAT5. Chembiochem 9 723-727. (doi:10.1002/cbic.200700701)

Ohara-Imaizumi M, Kim H, Yoshida M, Fujiwara T, Aoyagi K, Toyofuku Y, Nakamichi Y, Nishiwaki C, Okamura T, Uchida T et al. 2013 Serotonin regulates glucose-stimulated insulin secretion from pancreatic $\beta$ cells during pregnancy. PNAS 110 19420-19425. (doi:10.1073/pnas. 1310953110)

Park SH, Yamashita H, Rui H \& Waxman DJ 2001 Serine phosphorylation of GH-activated signal transducer and activator of transcription $5 \mathrm{a}$ (STAT5a) and STAT5b: impact on STAT5 transcriptional activity. Molecular Endocrinology 15 2157-2171. (doi:10.1210/mend.15.12.0746)

Qian L, Lopez V, Seo YA \& Kelleher SL 2009 Prolactin regulates ZNT2 expression through the JAK2/STAT5 signaling pathway in mammary cells. American Journal of Physiology. Cell Physiology 297 C369-C377. (doi:10.1152/ajpcell.00589.2008)

Rieck S \& Kaestner KH 2010 Expansion of $\beta$-cell mass in response to pregnancy. Trends in Endocrinology and Metabolism 21 151-158. (doi:10.1016/j.tem.2009.11.001)

Sadowski HB, Shuai K, Darnell JE Jr \& Gilman MZ 1993 A common nuclear signal transduction pathway activated by growth factor and cytokine receptors. Science 261 1739-1744. (doi:10.1126/science.8397445)

Saisho Y, Butler AE, Manesso E, Elashoff D, Rizza RA \& Butler PC 2013 3-cell mass and turnover in humans: effects of obesity and aging. Diabetes Care 36 111-117. (doi:10.2337/dc12-0421)

Schraenen A, Lemaire K, de Faudeur G, Hendrickx N, Granvik M, Van Lommel L, Mallet J, Vodjdani G, Gilon P, Binart N et al. 2010 Placental lactogens induce serotonin biosynthesis in a subset of mouse $\beta$ cells during pregnancy. Diabetologia 53 2589-2599. (doi:10.1007/ s00125-010-1913-7)

Seale P, Kajimura S, Yang W, Chin S, Rohas LM, Uldry M, Tavernier G Langin D \& Spiegelman BM 2007 Transcriptional control of brown fat determination by PRDM16. Cell Metabolism 6 38-54. (doi:10.1016/ j.cmet.2007.06.001)

Smith SB, Ee HC, Conners JR \& German MS 1999 Paired-homeodomain transcription factor PAX4 acts as a transcriptional repressor in early pancreatic development. Molecular and Cellular Biology 19 8272-8280. 
Soldaini E, John S, Moro S, Bollenbacher J, Schindler U \& Leonard WJ 2000 DNA binding site selection of dimeric and tetrameric Stat5 proteins reveals a large repertoire of divergent tetrameric Stat5a binding sites. Molecular and Cellular Biology 20 389-401. (doi:10.1128/MCB.20.1.389401.2000)

Sorenson RL \& Brelje TC 2009 Prolactin receptors are critical to the adaptation of islets to pregnancy. Endocrinology 150 1566-1569. (doi:10.1210/en.2008-1710)

Yamashita H, Xu J, Erwin RA, Farrar WL, Kirken RA \& Rui H 1998 Differential control of the phosphorylation state of proline-juxtaposed serine residues Ser725 of Stat5a and Ser730 of Stat5b in prolactin- sensitive cells. Journal of Biological Chemistry 273 30218-30224. (doi:10.1074/jbc.273.46.30218)

Yamato E, Tashiro F \& Miyazaki J 2013 Microarray analysis of novel candidate genes responsible for glucose-stimulated insulin secretion in mouse pancreatic $\beta$ cell line MIN6. PLoS ONE 8 e61211. (doi:10.1371/ journal.pone.0061211)

Zhang H, Zhang J, Pope CF, Crawford LA, Vasavada RC, Jagasia SM \& Gannon M 2010 Gestational diabetes mellitus resulting from impaired $\beta$-cell compensation in the absence of FoxM1, a novel downstream effector of placental lactogen. Diabetes 59 143-152. (doi:10.2337/db090050)

Received in final form 29 June 2015

Accepted 1 July 2015

Accepted Preprint published online 1 July 2015
Published by Bioscientifica Ltd. 